\title{
Aplikasi Manajemen Praktikum Laboratorium Software Engineering Sistem Komputer Universitas Diponegoro
}

\author{
Diaz Wicaksono, Ir. Kodrat Iman Satoto, M.T., Rinta Kridalukmana, S.Kom., M.T. \\ Program Studi Sistem Komputer Fakultas Teknik Universitas Diponegoro \\ Jalan Prof. Sudharto, Tembalang, Semarang, Indonesia \\ wicaksonodiaz@gmail.com
}

\begin{abstract}
Lab activities are activities that are routinely performed by college students, lab activities shall be carried out as part of the lectures. In practice, there is no doubt often occur int the organization of costraints associated with the lab, such as information dissemination, creation of assessment list and data is not centralized. One of the lab activities is performed in the Laboratory of Computer System Software Engineering Diponegoro University. The labs require a lab management applications in order to improve work efficiency and improve the smooth operation of the lab.

Practical Application Management consist of client and a blog applications, created using Visual C\# for client, ASP.NET for the blog and with the .NET Framework technology also Microsoft SQL Server databases. Development method was performed using the waterfall method, whereas in application design using UML modeling.

The expected result from design of this application is to create an application that consist of client and blog application to manage data from many lab activities in a university lab, such as processing data from various laboratory practitioner, creation of assessment list and dissemination of information about the lab activities.
\end{abstract}

Key Terms: practical application management, .net framework, visual c\#

\section{PENDAHULUAN}

$\mathrm{P}$ ERKEMBANGAN teknologi informasi dan komunikasi menjadi semakin pesat dari tahun ke tahun. Hampir semua aspek selalu melibatkan teknologi informasi. Namun pada kenyataan lapangan, banyak organisasi belum memanfaatkan teknologi tersebut untuk tujuannya sehingga mengalami beberapa kendala. Salah satu contoh di universitas di fakultas teknik, hampir semua memiliki paling tidak sebuah laboratorium yang digunakan untuk praktikum mahasiswa. Tidak sedikit laboratorium yang belum menggunakan sistem tersendiri untuk penanganan praktikumnya.

Hasil yang diharapkan dari penelitian ini adalah terwujudnya sebuah aplikasi yang dapat mengelola data dari banyak kegiatan praktikum di suatu universitas, seperti mengolah data praktikan dari berbagai praktikum, pembuatan daftar nilai dan penyebaran informasi mengenai praktikum.

\section{TINJAUAN PUSTAKA}

\section{A. Sistem Informasi}

Pengertian sistem informasi dapat didefinisikan sebagai berikut :

1) Suatu sistem yang dibuat oleh manusia yang terdiri dari komponen-komponen dalam organisasi untuk mencapai suatu tujuan yaitu menyajikan informasi.

2) Sekumpulan prosedur organisasi yang pada saat dilaksanakan akan memberikan informasi bagi pengambil keputusan dan atau untuk mengendalikan organisasi.

3) Suatu sistem di dalam suatu organisasi yang mempertemukan kebutuhan penolahan transaksi, mendukung operasi, bersifat manajerial dan kegiatan strategi dari suatu organisasi dan menyediakan pihak luar tertentu dengan laporan-laporan yang diperlukan.

\section{B. $S D L C$}

SDLC atau Software Development Life Cycle atau sering disebut juga System Development Life Cycle adalah proses mengembangkan atau mengubah suatu sistem perangkat lunak dengan menggunakan model-model dan metodologi yang digunakan orang untuk mengembangkan sistem-sistem perangkat lunak sebelumnya (berdasarkan best practice atau cara-cara yang sudah teruji baik).

Tahapan yang ada pada SDLC secara global adalah sebagai beriku :

1) Inisiasi (initiation)

2) Pengembangan konsep sistem (system concept development)

3) Perencanaan (planning)

4) Analisis kebutuhan (requirement analysis)

5) Desain (design)

6) Pengembangan (development)

7) Integrasi dan pengujian (integration and test)

8) Implementasi (implementation)

9) Operasi dan pemeliharaan (operation and maintenance)

10) Disposisi (disposition)

C. $U M L$

UML adalah bahasa spesifikasi standar yang dipergunakan untuk mendokumentasikan, menspesifikasikan dan membangun perangkat lunak. UML merupakan metodologi dalam mengembangkan sistem berorientasi objek dan juga merupakan alat untuk mendukung pengembangan sistem. UML saat ini sangat banyak dipergunakan dalam dunia industri yang merupakan standar bahasa pemodelan umum dalam industri perangkat lunak dan pengembangan sistem. 


\section{Microsoft Visual C\#}

C\# merupakan bahasa pemrograman berbasis objek dan mendukung secara penuh konsep pemrograman berorientasi objek seperti inheritance, polymorphism, encapsulation dan abstraction. Selain pemrograman objek, C\# juga mendukung pemrograman berorientasi komponen (component-oriented programming), yang memungkinkan kita untuk menetapkan unit fungsional (komponen) yang berdiri sendiri dan terdokumentasi dengan menyediakan sebuah model dengan properties, method, events dan metadata tentang komponen yang dimaksud. C\# mendukung konsep tersebut secara langsung dalam bahasanya.

\section{E. ASP.NET}

ASP.NET digunakan untuk membuat aplikasi web, dan merupakan pilihan yang lebih baik ketika menggunakan teknologi dari Microsoft. ASP.NET dibuat oleh Microsoft pada awal tahun 2000-an sebagai bagian dari inisiatif .NET Framework, yang menawarkan sebuah lingkungan yang sepaket ketika membuat dan menjalankan aplikasi untuk para developer Windows.

\section{PERANCANGAN PENELITIAN}

\section{A. Tahap Perancangan Sistem}

Tahapan perancangan sistem memiliki tujuan untuk mendesain sistem baru yang dapat menyelesaikan masalahmasalah yang dihadapi organisasi atau perusahaan. Software Development Live Cycle adalah proses mengembangkan atau mengubah suatu sistem perangkat lunak dengan menggunakan model-model dan metodologi yang digunakan orang untuk mengembangkan sistem-sistem perangkat lunak sebelumnya. Model yang digunakan dalam penelitian ini adalah model waterfall. Model waterfall terdiri dari 4 tahap yaitu Analisis, Desain, Pengodean, Pengujian dan Pemeliharaan.

\section{B. Analisis Kebutuhan Perangkat Lunak}

Sistem yang dibuat terkadang tidak sesuai dengan keinginan dari pengguna sistem yang memungkinkan terjadi kesalahan. Hal ini sering terjadi apabila dalam pembuatan sebuah sistem tidak diawali dengan analisis kebutuhan yang mendasar dan rinci. Analisis kebutuhan dapat dilakukan melalui wawancara dengan pihak-pihak terkait dan pengamatan dari lingkungan di mana sistem akan dibangun.

\section{Deskripsi Umum}

Laboratorium Software Engineering Sistem Komputer Universitas Diponegoro merupakan laboratorium yang digunakan untuk berbagai kegiatan perkuliahan, salah satunya adalah kegiatan praktikum. Kegiatan praktikum rutin dilaksanakan hampir setiap semester sesuai dengan jadwal yang telah ditentukan. Demi menunjang kegiatan praktikum tersebut, diperlukansebuah aplikasi yang dapat mengatur dan memanajemen kegiatan praktikum yang sedang dilaksanakan. Berdasarkan hasil pengamatan dan pengalaman penulis sendiri sebagai asisten praktikum, diharapkan aplikasi yang dibuat tersebut dapat :

1) Mengelola berbagai kegiatan praktikum yang dilaksanakan di Laboratorium Software Engineering Sistem Komputer Universitas Diponegoro.

2) Memusatkan kegiatan asisten dalam memanajemen praktikum dalam sebuah sistem aplikasi yang dapat mengelola kegiatan praktikum, membuat penilaian, mengelola data praktikan dan penyebaran informasi praktikum.

\section{Kebutuhan Pengguna}

Setelah mendeskripsikan tahapan kerja dan disertai informasi serta kendala yang ada, didapatkan kebutuhan untuk kemudahan memanajemen kegiatan praktikum yang dilakukan di Laboratorium Software Engineering Sistem Komputer Universitas Diponegoro. Kebutuhan tersebut adalah :

1) Memanajemen berbagai kegiatan praktikum yang dilakukan di Laboratorium Software Engineering Sistem Komputer Universitas Diponegoro.

2) Mengelola data kegiatan masing-masing praktikum.

3) Mengelola data asisten praktikum.

4) Mengelola informasi terkait kegiatan praktikum.

5) Mengelola data tugas akhir praktikan.

6) Mencetak daftar absensi asisten.

7) Mencetak daftar absensi praktikan.

8) Mencetak daftar nilai praktikan.

9) Menampilkan statistik nilai dari kegiatan masing-masing praktikum.

Aktor yang terlibat

Berdasarkan dari deskripsi umum, dalam pembuatan aplikasi manajemen praktikum ini terdapat beberapa aktor yang terlibat, yaitu :

1) Asisten

Asisten yang dalam hal ini adalah asisten praktikum memiliki wewenang untuk:

a) Mengelola project kegiatan praktikum.

b) Mengelola data kegiatan praktikum.

c) Mengelola data mahasiswa.

d) Mengelola data asisten.

e) Mengelola pengguna / user aplikasi.

f) Mencetak daftar nilai praktikan.

g) Mencetak daftar absensi asisten dan praktikan.

h) Mengelola informasi terkait kegiatan praktikum.

i) Mengelola data tugas akhir praktikan.

j) Menampilkan statistik kegiatan praktikum.

k) Mengirimkan email berisi daftar nilai praktikum.

2) Praktikan

a) Mencari informasi terkait kegiatan praktikum.

b) Mengomentari informasi terkait kegiatan praktikum

c) Melihat daftar nilai praktikan.

d) Melihat statistik kegiatan praktikum.

\section{Desain}

Tahap perancangan / desain perangkat lunak merupakan proses multi langkah dan berfokus pada beberapa atribut perangkat lunak. Proses ini berdasarkan dari analisa sebelumnya sehingga menciptakan sebuah rancangan yang sesuai dengan kebutuhan dari pihak terkait. Dalam perancangan perangkat lunak ini, digunakan Entity Relationship Diagram (ERD) untuk pemodelan basis data dan UML untuk pemodelan perangkat lunak.

Entity Relationship Diagram

Entity Relationship Diagram (ERD) adalah salah satu metode pemodelan data yang digunakan untuk menggambarkan basis data. ERD dikembangkan berdasarkan teori himpunan dalam bidang matematika. ERD digunakan untuk pemodelan basis data relasional. Berikut adalah daftar entitas yang terlibat dalam desain basis data aplikasi manajemen praktikum : 
TABEL I

ENTITAS YANG TERLIBAT

\begin{tabular}{|c|c|c|}
\hline Entitas & $\begin{array}{c}\text { Jenis } \\
\text { Entitas }\end{array}$ & Keterangan \\
\hline 1) Mahe & Entitas Kuat & $\begin{array}{l}\text { Entitas yang berisi data mahasiswa } \\
\text { Sistem Komputer Universitas } \\
\text { Diponegoro, keberadaan tidak } \\
\text { bergantung pada entitas lain. }\end{array}$ \\
\hline 2) Asisten & Entitas Kuat & $\begin{array}{l}\text { Entitas yang berisi data asisten yang } \\
\text { mengampu praktikum, keberadaan } \\
\text { tidak bergantung pada entitas lain. }\end{array}$ \\
\hline 3) Praktikum & $\begin{array}{l}\text { Entitas } \\
\text { Lemah }\end{array}$ & $\begin{array}{l}\text { Entitas yang berisi data praktikum } \\
\text { yang ada di Sistem Komputer } \\
\text { Universitas Diponegoro, keberadaan } \\
\text { bergantung pada entitas Dosen. }\end{array}$ \\
\hline 4) Dosen & Entitas Kuat & $\begin{array}{l}\text { Entitas yang berisi data dosen Sistem } \\
\text { Komputer Universitas Diponegoro, } \\
\text { keberadaan tidak bergantung pada } \\
\text { entitas lain. }\end{array}$ \\
\hline 5) Project & $\begin{array}{l}\text { Entitas } \\
\text { Lemah }\end{array}$ & $\begin{array}{l}\text { Entitas yang berisi data kegiatan } \\
\text { praktikum yang dilakukan, } \\
\text { keberadaan bergantung pada entitas } \\
\text { Dosen, Asisten dan Mahasiswa. }\end{array}$ \\
\hline 6) Informasi & $\begin{array}{l}\text { Entitas } \\
\text { Lemah }\end{array}$ & $\begin{array}{l}\text { Entitas yang berisi informasi } \\
\text { mengenai praktikum, keberadaan } \\
\text { bergantung pada entitas Project }\end{array}$ \\
\hline 7) User & Entitas Kuat & $\begin{array}{l}\text { Entitas yang berisi informasi } \\
\text { pengguna aplikasi, keberadaan tidak } \\
\text { bergantung pada entitas lain. }\end{array}$ \\
\hline 8) Komentar & $\begin{array}{l}\text { Entitas } \\
\text { Lemah }\end{array}$ & $\begin{array}{l}\text { Entitas yang berisi komentar dari } \\
\text { pengunjung terhadap entitas } \\
\text { Informasi, keberadaan bergantung } \\
\text { pada entitas Informasi. }\end{array}$ \\
\hline
\end{tabular}

\section{Use Case Diagaram}

Berikut adalah diagram use case dari aplikasi manajemen praktikum :

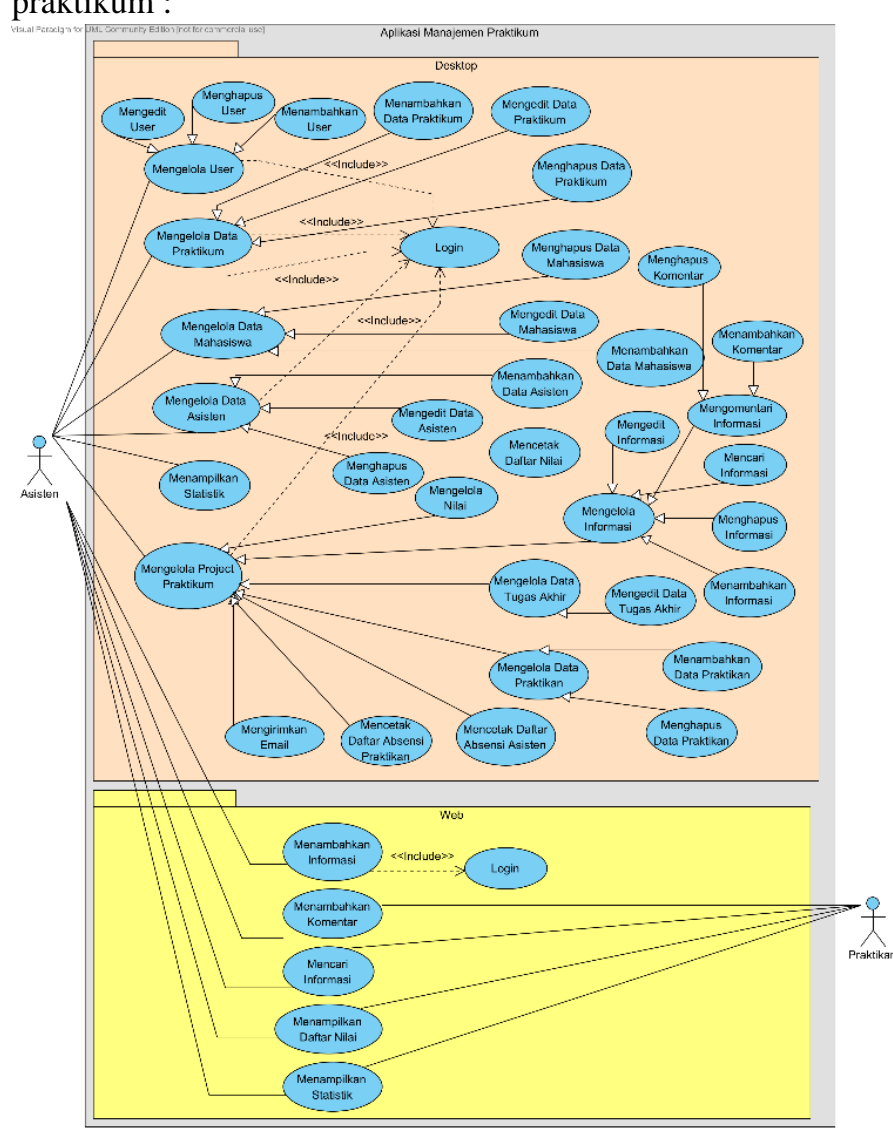

Gambar 1. Use case diagaram aplikasi manajemen praktikum

\section{Antarmuka Pengguna}

Berikut ini merupakan antarmuka yang dimiliki aplikasi manajemen praktikum :

1. Aplikasi Client
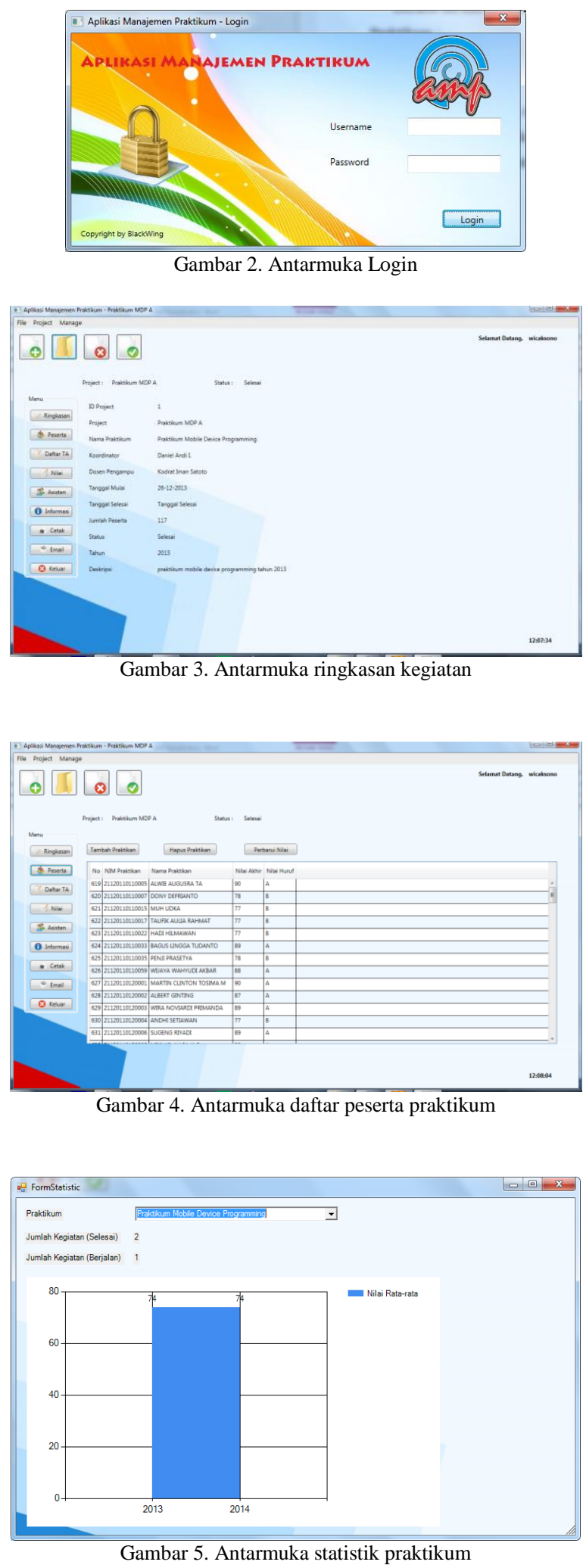

2. Aplikasi Web 


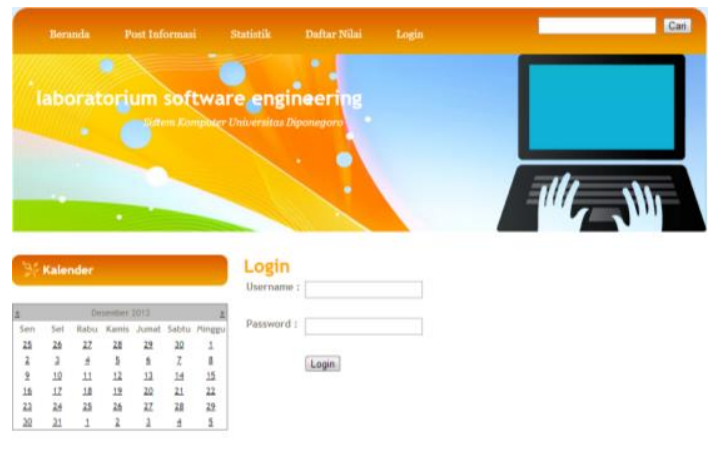

Gambar 6. HalamanLogin

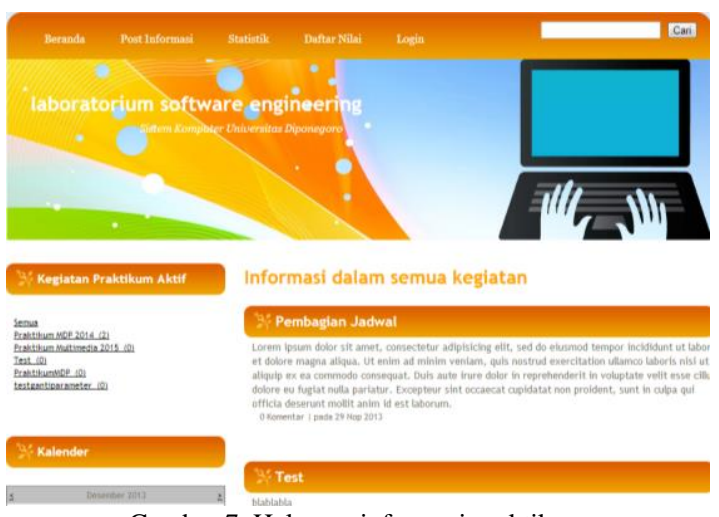

Gambar 7. Halaman informasi praktikum

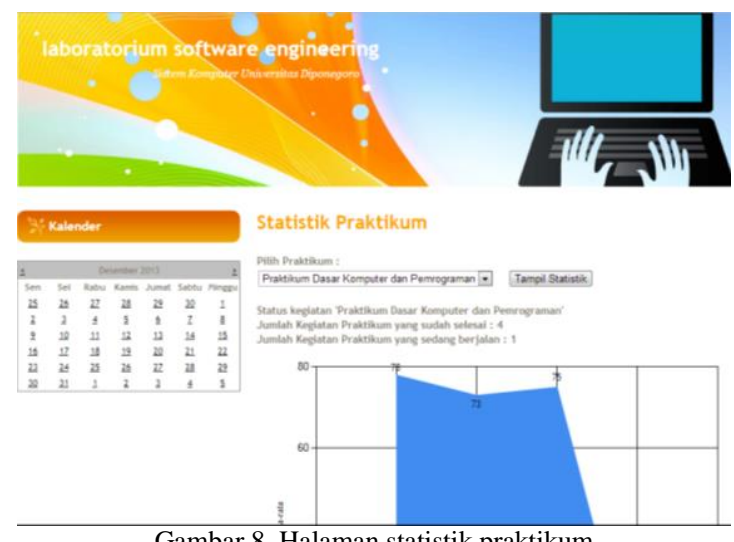

Gambar 8. Halaman statistik praktikum

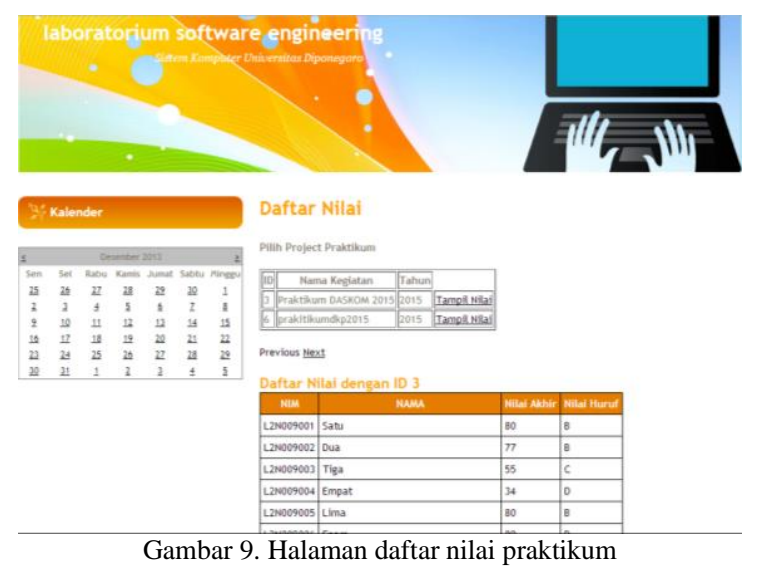

\section{Analisis Hasil Penelitian Dan Pembahasan}

\section{A. Basis Data}

Aplikasi manajemen praktikum menggunakan basis data SQL Server untuk menyimpan data. Pada proses pembuatannya, basis data dibuat pada komputer lokal. Dengan menggunakan Tools Microsoft SQL Server Management Studio, pembuatan basis data dan tabel-tabelnya dapat secara mudah menggunakan GUI tanpa perlu menuliskan kode-kode pembuatan basis data.

\section{B. Program}

Langkah selanjutnya jika basis data sudah dibuat beserta tabel-tabelnya yaitu penerapan program. Dalam pembuatan program terdiri dari proses pembuatan user interface / tampilan dan logika aplikasi. Microsoft Visual Studio sudah menyediakan IDE untuk men-desain user interface sehingga programmer tidak sepenuhnya menuliskan kode untuk membuat tampilan program. Selanjutnya adalah membuat logika aplikasi, logika aplikasi yang berupa kode-kode program dalam bentuk class menentukan bagaimana aplikasi akan berjalan.

\section{Pengujian}

Proses pengujian dilakukan menggunaakn metode blackbox berdasarkan fungsi dari aplikasi yang tertera pada use case diagram. Proses pengujian dilakukan untuk mengetahui apakah fungsi aplikasi yang diharapkan dapat berfungsi dengan baik.

Pengujian dimulai pada bagian user / pengguna. Bagian ini meliputi proses login, penambahan, ubah dan penghapusan data user. Pengujian masing-masing sesuai dengan use case dapat dilihat pada tabel-tabel berikut :

TABEL II

PENGUJIAN USER

\begin{tabular}{|c|c|c|c|}
\hline $\begin{array}{l}\text { Nama } \\
\text { Pengujian }\end{array}$ & $\begin{array}{l}\text { Bentuk } \\
\text { Pengujian }\end{array}$ & $\begin{array}{l}\text { Hasil yang } \\
\text { diharapkan }\end{array}$ & $\begin{array}{l}\text { Hasil } \\
\text { Pengujian }\end{array}$ \\
\hline $\begin{array}{l}\text { Pengujian } \\
\text { login }\end{array}$ & $\begin{array}{l}\text { Memasukkan } \\
\text { username dan } \\
\text { password yang } \\
\text { digunakan untuk } \\
\text { login }\end{array}$ & $\begin{array}{l}\text { Muncul menu } \\
\text { utama aplikasi }\end{array}$ & Berhasil \\
\hline $\begin{array}{l}\text { Pengujian } \\
\text { tambah data } \\
\text { user }\end{array}$ & $\begin{array}{l}\text { Memasukkan data } \\
\text { user baru dan } \\
\text { menyimpannya }\end{array}$ & $\begin{array}{l}\text { Muncul pesan data } \\
\text { user berhasil } \\
\text { ditambahkan dan } \\
\text { data tersebut } \\
\text { tampil pada daftar }\end{array}$ & Berhasil \\
\hline $\begin{array}{l}\text { Pengujian } \\
\text { ubah data } \text { user }\end{array}$ & $\begin{array}{l}\text { Memilh data user } \\
\text { yang tersedia dan } \\
\text { mengubah } \\
\text { informasinya }\end{array}$ & $\begin{array}{l}\text { Muncul pesan data } \\
\text { user berhasil } \\
\text { diperbarui dan } \\
\text { data yang baru } \\
\text { muncul dalam } \\
\text { daftar }\end{array}$ & Berhasil \\
\hline $\begin{array}{l}\text { Pengujian } \\
\text { hapus data } \\
\text { user }\end{array}$ & $\begin{array}{l}\text { Memilih data } \text { user } \\
\text { tertentu dan } \\
\text { menghapus data } \\
\text { tersebut dengan } \\
\text { mengklik tombol } \\
\text { hapus }\end{array}$ & $\begin{array}{l}\text { Muncul pesan data } \\
\text { user berhasil } \\
\text { dihapus dan data } \\
\text { yang dihapus } \\
\text { menghilang dari } \\
\text { daftar }\end{array}$ & Berhasil \\
\hline
\end{tabular}

TABEL III

PENGUJIAN DATA PRAKTIKUM

\begin{tabular}{|l|l|l|l|}
\hline $\begin{array}{l}\text { Nama Pengujian } \\
\text { Pengujian } \\
\text { Pambah data } \\
\text { praktikum }\end{array}$ & $\begin{array}{l}\text { Memasukkan data } \\
\text { praktikum baru } \\
\text { dan } \\
\text { menyimpannya }\end{array}$ & $\begin{array}{l}\text { Muncul pesan data } \\
\text { diharapkan } \\
\text { praktikum berhasil } \\
\text { ditambahkan dan } \\
\text { data tersebut } \\
\text { tampil pada daftar }\end{array}$ & Berhasil \\
\hline $\begin{array}{l}\text { Pengujian } \\
\text { ubah data } \\
\text { praktikum }\end{array}$ & $\begin{array}{l}\text { Memilh data } \\
\text { praktikum yang } \\
\text { tersedia dan } \\
\text { mengubah }\end{array}$ & $\begin{array}{l}\text { Muncul pesan data } \\
\text { praktikum berhasil } \\
\text { diperbarui dan } \\
\text { data yang baru } \\
\text { muncul dalam } \\
\text { informasinya }\end{array}$ & \\
\hline
\end{tabular}




\begin{tabular}{|l|l|l|l|}
\hline $\begin{array}{l}\text { Pengujian } \\
\text { hapus data } \\
\text { praktikum }\end{array}$ & $\begin{array}{l}\text { Memilih data } \\
\text { praktikum }\end{array}$ & $\begin{array}{l}\text { Muncul pesan data } \\
\text { praktikum berhasil }\end{array}$ & Berhasil \\
tertentu dan & dihapus dan data & \\
menghapus data & yang dihapus & \\
& $\begin{array}{l}\text { tersebut dengan } \\
\text { mengklik tombol } \\
\text { hapus }\end{array}$ & menghilang dari & \\
daftar & \\
\hline
\end{tabular}

\begin{tabular}{|c|c|c|c|}
\hline $\begin{array}{l}\text { Pengujian } \\
\text { hapus } \\
\text { informasi } \\
\text { kegiatan }\end{array}$ & $\begin{array}{l}\text { Memilih } \\
\text { informasi } \\
\text { kegiatan } \\
\text { tertentu dan } \\
\text { menghapus data } \\
\text { tersebut dengan } \\
\text { mengklik } \\
\text { tombol hapus }\end{array}$ & $\begin{array}{lr}\text { Muncul r } & \text { pesan } \\
\text { informasi } & \text { kegiatan } \\
\text { berhasil dihapus dan } \\
\text { informasi } & \text { tersebut } \\
\text { menghilang } & \text { dari } \\
\text { daftar } & \end{array}$ & Berhasil \\
\hline $\begin{array}{l}\text { Pengujian } \\
\text { pencarian } \\
\text { informasi } \\
\text { kegiatan }\end{array}$ & $\begin{array}{l}\text { Memasukkan } \\
\text { kata kunci } \\
\text { pencarian } \\
\text { tertentu pada } \\
\text { kotak isian yang } \\
\text { ada }\end{array}$ & $\begin{array}{l}\text { Informasi kegiatan } \\
\text { yang berhubungan } \\
\text { dengan katan kunci } \\
\text { yang ditampilkan } \\
\text { dalam daftar }\end{array}$ & Berhasil \\
\hline $\begin{array}{l}\text { Pengujian } \\
\text { ubah data } \\
\text { tugas akhir } \\
\text { praktikum }\end{array}$ & $\begin{array}{l}\text { Memilih } \\
\text { praktikan dan } \\
\text { mengubah } \\
\text { informasi tugas } \\
\text { akhir } \\
\text { praktikumnya }\end{array}$ & $\begin{array}{l}\text { Muncul pesan data } \\
\text { tugas akhir } \\
\text { praktikum berhasil } \\
\text { diperbarui dan data } \\
\text { yang baru muncul } \\
\text { dalam daftar }\end{array}$ & Berhasil \\
\hline $\begin{array}{l}\text { Pengujian } \\
\text { tambah data } \\
\text { praktikan }\end{array}$ & $\begin{array}{l}\text { Memilih } \\
\text { praktikan dari } \\
\text { daftar } \\
\text { mahasiswa } \\
\text { yang tersedia } \\
\text { dan mengklik } \\
\text { tombol tambah }\end{array}$ & $\begin{array}{l}\text { Muncul pesan data } \\
\text { praktikan berhasil } \\
\text { ditambahkan dan } \\
\text { data tersebut muncul } \\
\text { dalam daftar }\end{array}$ & Berhasil \\
\hline $\begin{array}{l}\text { Pengujian } \\
\text { hapus data } \\
\text { praktikan }\end{array}$ & $\begin{array}{l}\text { Memilih } \\
\text { praktikan } \\
\text { tertentu dan } \\
\text { menghapus data } \\
\text { tersebut dengan } \\
\text { mengklik } \\
\text { tombol hapus }\end{array}$ & $\begin{array}{l}\text { Muncul pesan data } \\
\text { praktikan berhasil } \\
\text { dihapus dan data } \\
\text { tersebut menghilang } \\
\text { dari daftar }\end{array}$ & Berhasil \\
\hline $\begin{array}{l}\text { Pengujian } \\
\text { cetak daftar } \\
\text { absensi } \\
\text { asisten }\end{array}$ & $\begin{array}{l}\text { Memasukkan } \\
\text { jumlah shift, } \\
\text { semester serta } \\
\text { tanggal } \\
\text { kemudian } \\
\text { mengklik } \\
\text { tombol cetak }\end{array}$ & $\begin{array}{lr}\begin{array}{l}\text { Muncul pesan file } \\
\text { (word) }\end{array} & \text { berhasil } \\
\text { dibuat dan file } & \text { dan } \\
\text { tersebut } & \text { muncul } \\
\text { dalam } & \text { daftar } \\
\text { dokumen } & \text { serta dapat } \\
\text { dibuka } & \end{array}$ & Berhasil \\
\hline $\begin{array}{l}\text { Pengujian } \\
\text { cetak daftar } \\
\text { absensi } \\
\text { praktikan }\end{array}$ & $\begin{array}{l}\text { Memasukkan } \\
\text { jumlah } \\
\text { pertemuan yang } \\
\text { dilakukan dan } \\
\text { semester } \\
\text { praktikum } \\
\text { kemudian } \\
\text { mengklik } \\
\text { tombol cetak }\end{array}$ & $\begin{array}{lr}\text { Muncul pesan file } \\
\text { (word) } & \text { berhasil } \\
\text { dibuat dan file } \\
\text { tersebut } \\
\text { dalam muncul } \\
\text { dokumen serta dapat } \\
\text { dibuka }\end{array}$ & Berhasil \\
\hline $\begin{array}{l}\text { Pengujian } \\
\text { tambah } \\
\text { komentar }\end{array}$ & $\begin{array}{l}\text { Memasukkan } \\
\text { komentar pada } \\
\text { kotak isian yang } \\
\text { tersedia dan } \\
\text { mengklik } \\
\text { tombol post }\end{array}$ & $\begin{array}{l}\text { Muncul pesan } \\
\text { komentar berhasil } \\
\text { ditambahkan dan } \\
\text { data tersebut muncul } \\
\text { dalam daftar }\end{array}$ & Berhasil \\
\hline $\begin{array}{l}\text { Pengujian } \\
\text { hapus } \\
\text { komentar }\end{array}$ & $\begin{array}{l}\text { Memilih } \\
\text { komentar } \\
\text { tertentu dari } \\
\text { daftar dan } \\
\text { mengklik } \\
\text { tombol delete }\end{array}$ & $\begin{array}{l}\text { Muncul pesan } \\
\text { komentar berhasil } \\
\text { dihapus dan data } \\
\text { tersebut menghilang } \\
\text { dari daftar }\end{array}$ & Berhasil \\
\hline $\begin{array}{l}\text { Pengujian } \\
\text { kirim email }\end{array}$ & $\begin{array}{l}\text { Mengirim email } \\
\text { yang berisi } \\
\text { attachment } \\
\text { daftar nilai ke } \\
\text { alamat yang } \\
\text { dituju }\end{array}$ & $\begin{array}{l}\text { Email yang dikirim } \\
\text { beserta attachment- } \\
\text { nya berhasil sampai } \\
\text { ke alamat yang } \\
\text { dituju }\end{array}$ & Berhasil \\
\hline $\begin{array}{l}\text { Pengujian } \\
\text { menampilkan } \\
\text { statistik }\end{array}$ & $\begin{array}{l}\text { Memilih salah } \\
\text { satu dari daftar } \\
\text { praktikum yang } \\
\text { ada untuk } \\
\text { ditampilkan } \\
\text { statistiknya }\end{array}$ & $\begin{array}{l}\text { Tampil statistik nilai } \\
\text { rata-rata untuk tiap } \\
\text { kegiatan yang telah } \\
\text { selesai dilaksanakan }\end{array}$ & Berhasil \\
\hline
\end{tabular}

TABEL V

PENGUJIAN DATA ASISTEN

\begin{tabular}{|l|l|l|l|}
\hline $\begin{array}{l}\text { Nama } \\
\text { Pengujian }\end{array}$ & $\begin{array}{l}\text { Bentuk } \\
\text { Pengujian }\end{array}$ & $\begin{array}{l}\text { Hasil yang } \\
\text { diharapkan }\end{array}$ & $\begin{array}{l}\text { Hasil } \\
\text { Pengujian }\end{array}$ \\
\hline $\begin{array}{l}\text { Pengujian } \\
\text { tambah data } \\
\text { asisten }\end{array}$ & $\begin{array}{l}\text { Memasukkan } \\
\text { data asisten } \\
\text { baru dan } \\
\text { menyimpannya }\end{array}$ & $\begin{array}{l}\text { Muncul pesan data } \\
\text { asisten berhasil } \\
\text { ditambahkan dan } \\
\text { data tersebut tampil } \\
\text { pada daftar }\end{array}$ & Berhasil \\
\hline $\begin{array}{l}\text { Pengujian } \\
\text { ubah data } \\
\text { asisten da }\end{array}$ & $\begin{array}{l}\text { Memilh data } \\
\text { asisten yang } \\
\text { tersedia dan } \\
\text { mengubah } \\
\text { informasinya }\end{array}$ & $\begin{array}{l}\text { Muncul pesan data } \\
\text { asisten berhasil } \\
\text { diperbarui dan data } \\
\text { yang baru muncul } \\
\text { dalam daftar Berhasil }\end{array}$ & \\
\hline $\begin{array}{l}\text { Pengujian } \\
\text { hapus data } \\
\text { asisten }\end{array}$ & $\begin{array}{l}\text { Memilih data } \\
\text { asisten tertentu } \\
\text { dan menghapus } \\
\text { data tersebut } \\
\text { dengan } \\
\text { mengklik } \\
\text { tombol hapus }\end{array}$ & $\begin{array}{l}\text { Muncul pesan data } \\
\text { asisten berhasil } \\
\text { dihapus dan data } \\
\text { yang dihapus } \\
\text { menghilang dari } \\
\text { daftar Brasil }\end{array}$ & \\
\hline
\end{tabular}

TABEL VI

PENGUJIAN DATA KEGIATAN PRAKTIKUM

\begin{tabular}{|c|c|c|c|}
\hline $\begin{array}{l}\text { Nama } \\
\text { Pengujian }\end{array}$ & $\begin{array}{l}\text { Bentuk } \\
\text { Pengujian }\end{array}$ & $\begin{array}{ll}\begin{array}{l}\text { Hasil } \\
\text { diharapkan }\end{array} & \text { yang } \\
\end{array}$ & $\begin{array}{l}\text { Hasil } \\
\text { Pengujian }\end{array}$ \\
\hline $\begin{array}{l}\text { Pengujian } \\
\text { mencetak } \\
\text { daftar nilai }\end{array}$ & $\begin{array}{l}\text { Memasukkan } \\
\text { beberapa } \\
\text { parameter yang } \\
\text { tersedia } \\
\text { kemudian } \\
\text { mengklik } \\
\text { tombol cetak }\end{array}$ & $\begin{array}{l}\text { Muncul pesan file } \\
\text { (excel) berhasil } \\
\text { dibuat dan file } \\
\text { tersebut muncul } \\
\text { pada daftar dokumen } \\
\text { serta dapat dibuka. }\end{array}$ & Berhasil \\
\hline $\begin{array}{l}\text { Pengujian } \\
\text { tambah } \\
\text { informasi } \\
\text { kegiatan }\end{array}$ & $\begin{array}{l}\text { Memasukkan } \\
\text { informasi baru } \\
\text { dan mengklik } \\
\text { tombol post }\end{array}$ & $\begin{array}{l}\text { Muncul pesan } \\
\text { informasi kegiatan } \\
\text { berhasil } \\
\text { ditambahkan dan } \\
\text { data tersebut muncul } \\
\text { dalam daftar }\end{array}$ & Berhasil \\
\hline $\begin{array}{l}\text { Pengujian } \\
\text { ubah } \\
\text { informasi } \\
\text { kegiatan }\end{array}$ & $\begin{array}{l}\text { Memilih } \\
\text { informasi } \\
\text { kegiatan } \\
\text { tertentu dan } \\
\text { mengubah } \\
\text { informasinya }\end{array}$ & $\begin{array}{l}\text { Muncul pesan } \\
\text { informasi kegiatan } \\
\text { berhasil diperbarui } \\
\text { dan data yang baru } \\
\text { muncul dalam daftar }\end{array}$ & Berhasil \\
\hline
\end{tabular}


TABEL VII

PENGUJIAN APLIKASI WEB

\begin{tabular}{|c|c|c|c|}
\hline $\begin{array}{l}\text { Nama } \\
\text { Pengujian }\end{array}$ & $\begin{array}{l}\text { Bentuk } \\
\text { Pengujian }\end{array}$ & $\begin{array}{l}\text { Hasil yang } \\
\text { diharapkan }\end{array}$ & $\begin{array}{l}\text { Hasil } \\
\text { Pengujian }\end{array}$ \\
\hline $\begin{array}{l}\text { Pengujian } \\
\text { login }\end{array}$ & $\begin{array}{l}\text { Memasukkan } \\
\text { username dan } \\
\text { password yang } \\
\text { digunakan } \\
\text { untuk login }\end{array}$ & $\begin{array}{l}\text { Pengguna dialihkan } \\
\text { ke halaman utama } \\
\text { dan nama } \text { user } \\
\text { muncul di pojok } \\
\text { kanan atas halaman } \\
\text { web }\end{array}$ & Berhasil \\
\hline $\begin{array}{l}\text { Pengujian } \\
\text { menambahka } \\
\mathrm{n} \text { informasi }\end{array}$ & $\begin{array}{l}\text { Mengisi data } \\
\text { informasi } \\
\text { sesuai dengan } \\
\text { kolom yang } \\
\text { tersedia } \\
\text { kemudian } \\
\text { mengklik } \\
\text { tombol submit }\end{array}$ & $\begin{array}{l}\text { Muncul pesan data } \\
\text { asisten berhasil } \\
\text { diperbarui dan data } \\
\text { yang baru muncul } \\
\text { dalam daftar }\end{array}$ & Berhasil \\
\hline $\begin{array}{l}\text { Pengujian } \\
\text { menambahka } \\
\text { n komentar }\end{array}$ & $\begin{array}{l}\text { Memilih data } \\
\text { asisten tertentu } \\
\text { dan menghapus } \\
\text { data tersebut } \\
\text { dengan } \\
\text { mengklik } \\
\text { tombol hapus }\end{array}$ & $\begin{array}{l}\text { Muncul pesan data } \\
\text { asisten berhasil } \\
\text { dihapus dan data } \\
\text { yang dihapus } \\
\text { menghilang dari } \\
\text { daftar }\end{array}$ & Berhasil \\
\hline $\begin{array}{l}\text { Pengujian } \\
\text { mencari } \\
\text { informasi }\end{array}$ & $\begin{array}{l}\text { Mengisikan } \\
\text { kata kunci } \\
\text { pencarian dan } \\
\text { meng-klik } \\
\text { tombol cari }\end{array}$ & $\begin{array}{l}\text { Muncul informasi } \\
\text { yang mengandung } \\
\text { kata kunci yang } \\
\text { telah diisikan }\end{array}$ & Berhasil \\
\hline $\begin{array}{l}\text { Pengujian } \\
\text { menampilkan } \\
\text { daftar nilai }\end{array}$ & $\begin{array}{l}\text { Memilih salah } \\
\text { satu kegiatan } \\
\text { praktikum yang } \\
\text { telah selesai } \\
\text { dilaksanakan } \\
\text { dan meng-klik } \\
\text { tombol tampil }\end{array}$ & $\begin{array}{l}\text { Muncul daftar nilai } \\
\text { dari kegiatan } \\
\text { praktikum yang } \\
\text { dimaksud dalam } \\
\text { bentuk tabel }\end{array}$ & Berhasil \\
\hline $\begin{array}{l}\text { Pengujian } \\
\text { menampilkan } \\
\text { statistik }\end{array}$ & $\begin{array}{l}\text { Memilih salah } \\
\text { satu praktikum } \\
\text { yang akan } \\
\text { ditampilkan } \\
\text { statistiknya dan } \\
\text { meng-klik } \\
\text { tombol tampil }\end{array}$ & $\begin{array}{l}\text { Menampilkan } \\
\text { statistik nilai rata- } \\
\text { rata setiap kegiatan } \\
\text { yang telah selesai } \\
\text { dilakukan (jika ada) } \\
\text { dan menampilkan } \\
\text { status kegiatan yang } \\
\text { sedang berjalan dan } \\
\text { yang telah telesai }\end{array}$ & Berhasil \\
\hline
\end{tabular}

\section{KESIMPULAN DAN SARAN}

Pada bagian ini akan dijelaskan kesimpulan dan saran dari hasil penelitian dan pembahasan.

\section{A. Kesimpulan}

Berdasarkan hasil penelitian dan pembahasan, maka dapat diambil kesimpulan sebagai berikut :

1) Aplikasi Client dapat digunakan dalam ruang linkup jaringan Laboratorium Software Engineering Sistem Komputer Universitas Diponegoro namun dapat juga digunakan di luar lingkup jaringan tersebut namun membutuhkan koneksi internet untuk mengakses basis data pada server.

2) Aplikasi dibangun menggunakan .NET Framework versi 4.0 dan basis data Microsoft SQL Server 2008.

3) Berdasarkan data sampel kegiatan praktikum yang telah digunakan pada aplikasi, aplikasi tersebut dapat berjalan dengan baik.

4) Aplikasi ini disertai sebuah aplikasi web dalam bentuk blog untuk menampilkan informasi kegiatan praktikum.

5) Aplikasi manajemen praktikum memiliki fitur untuk menampilkan statistik dari kegiatan praktikum yang telah selesai dilakukan, sehingga statistik tersebut dapat dijadikan data acuan untuk pengembangan kegiatna
6) Aplikasi ini memiliki fitur keamanan tambahan berupa username dan password pada masing-masing kegiatan praktikum yang dilaksanakan agar data pada masingmasing kegiatan dapat terlindungi.

\section{B. Saran}

Terdapat beberapa saran dari hasil penelitian yaitu sebagai berikut :

1) Aplikasi manajemen praktikum ini dapat dikembangkan lebih lanjut dengan menambahkan fitur-fitur yang sekiranya diperlukan ke dalam aplikasi.

2) Perlu melakukan backup data secara berkala untuk menanggulangi jika terjadi kehilangan ataupun kerusakan data.

3) Pastikan dokumen-dokumen seperti daftar nilai praktikum disimpan dalam direktori yang seharusnya, karena memindahkan dokumen seperti daftar nilai menyebabkan daftar nilai tidak muncul dalam aplikasi.

4) Sistem ini menggunakan pengamanan tambahan ada setiap kegiatan praktikum yang dilakukan dengan menambahkan username dan password, model pengamanan tersebut dapat digantikan menggunakan sebuah login saja pada aplikasi namun memiliki role atau hak akses yang berbeda.

\section{DAFTAR PUSTAKA}

[1] A. S, Rosa dan Shalahuddin, M, Modul Pembelajaran Rekayasa Perangkat Lunak (Terstruktur dan Berorientasi Objek), Modula, Bandung, 2011.

[2] Bin Ladjamudin, Al-Bahra, Analisis dan Desain Sistem Informasi, Graha Ilmu, Yogyakarta, 2005.

[3] Bochicchio, Daniele. Mostrada, Stefano., and De Sanctis, Marco, ASP.NET 4.0 In Practice, Manning, New York, 2011.

[4] Dadik Setiawan, Taufik, Pengembangan Sistem Informasi Manajemen Laboratorium Teknik Mekanik Otomotif Pada SMK Berbasis Database Microsoft Access, Teknologi dan Kejuruan, 32, 95-106, 2009.

[5] Dorman, Scott, Sams Teach Yourself Visual C\# 2010 in 24 Hours : Complete Starter Kit, Sams, Indianapolis, 2010.

[6] Gata, Windu dan Gata, Grace., Sukses Membangun Aplikasi Penjualan dengan Java, PT Elex Media Komputindo, Jakarta, 2013.

[7] Kurniawan, Erick, Pemrograman Web Dinamis dengan ASP.NET 4.5, Andi, Yogyakarta, 2012.

[8] MacDonald, Matthew, Pro WPF in C\# 2010, Apress, New York, 2010.

[9] Riyanto, Slamet, Membangun Web Portal Multibahasa Joomla $1.5 X+C D$, PT Elex Media Komputindo, Jakarta, 2009.

[10] Sharp, John, Microsoft Visual C\# 2010 Step by Step, Microsoft Press, Washington, 2010.

[11] Susanti, Yeni, Pengembangan Sistem Informasi Manajemen Praktikum Jurusan Teknik Industri Universitas Andalas, Skripsi Strata 1, Universitas Andalas, 2007.

[12] Sutanta, Edhy, Sistem Informasi Manajemen, Graha Ilmu, Yogyakarta, 2003.

[13] Vieira, Robert, Professional Microsoft SQL Server 2008 Programming, Wiley, Indianapolis, 2009.

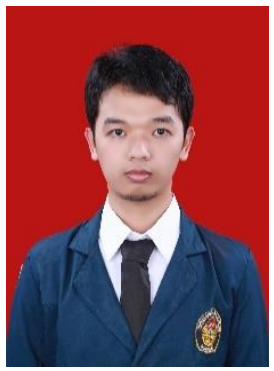

Diaz Wicaksono lahir di Brebes, Indonesia pada tahun 1991. Telah menempuh jenjang pendidikan dari SD hingga SMA di Bumiayu kemudian tahun 2009 melanjutkan studi Strata Satu (S1) di Program Studi Teknik Sistem Komputer Universitas Diponegoro Semarang. 